\title{
LITERASI BERMEDIA SOSIAL PADA REMAJA: Studi Pada Pengguna Instagram di Kota Lhokseumawe \\ Kamaruddin $^{1} \&$ Rizky $^{2}$ \\ ${ }^{1}$ Dosen Program Studi Ilmu Komunikasi Universitas \\ Malikussaleh \\ 2. Wartawan Zonamedia.co \\ Email: kamaruddin.hasan@unimal.ac.id
}

\begin{abstract}
ABSTRAK
Penelitian ini berjudul Literasi Bermedia Sosial pada Remaja (studi pada pengguna instagram di kota Lhokseumawe). Tujuan dari penelitian ini adalah untuk mengetahui dan mendeskripsikan literasi bermedia mengenai media sosial Instagram yang digunakan remaja kota Lhokseumawe. Pendekatan kualitatif bersifat deskriptif dengan menggunakan teori Framework New Media Literasi. Pengumpulan data yang digunakan dalam penelitian ini adalah observasi (pengamatan), interview (wawancara) dan dokumentasi. Teknik analisis data yang digunakan adalah mereduksi data, penyajian data dan penyimpulan data. Hasil penelitian menunjukkan bahwa informan telah menguasai Fungtional Consumig (kemampuan mengakses), Critical Consuming (kemampuan menganalisa, syntosis dan evaluasi), Fungtional Prosuming (kemampuan membagikan pesan), Critical Prosuming (kemampuan berpartisipasi dalam media). Kesimpulan dari penelitian ini adalah para remaja memiliki kemampuan dalam menggunakan dan menjalankan aplikasi Instagram dengan cara men Sign-up ke akun instagram yang dimiliki, kriteria signup adalah dengan cara mengunduh aplikasi, membuat nama akun, memasukkan email dan password. Para remaja juga telah mampu memanfaatkan Platform Instagram dalam mempublikasi konten layanan ini yang bersifat publik dengan memberikan pelayanan Friending, Following, Foto dan video, layanan ini menggunakan Platform Broser dan Aplikasi Instagram dan dapat memberi komentar terhadap konten yang dipublikasikan orang lain.
\end{abstract}

Kata Kunci: Literasi, Media sosial Instagram, Remaja.

\section{Pendahuluan}

Di era globalisasi perkembangan teknologi telah mempermudah aktifitas serta kebutuhan manusia, internet salah satu kecanggihan 
teknologi dalam bidang telekomunikasi yang dapat mempermudah manusia untuk saling terhubung antara satu dengan lainnya tanpa terhalang batas ruang dan waktu. Dengan penggunaan situs-situs media sosial melalui internet, interaksi antar personal manusia secara virtual menjadi konsumsi pokok dalam keseharian manusia saat ini dalam berkomunikasi, menerima dan menyampaikan informasi. Media sosial sendiri adalah suatu struktur sosial yang dibentuk dengan satu atau lebih tipe relasi spesifik, seperti nilai, pertemanan dan banyak hal lainnya, beberapa media sosial yang berkembang sangat pesat diantaranya Facebook, Twitter, Instagram, Path dan lain-lain. (http://ensiklo.com/2015/10/31/teori-jaringan-sosial/) di akses 19 oktober 2017.

Jika dilihat dari dampak positifnya, media sosial dapat digunakan sebagai tempat penyebaran informasi yang up to date sangat mudah menyebar melalui situs media sosial, hanya dalam tempo beberapa menit setelah kejadian, kita telah bisa menikmati informasi tersebut, berkomunikasi dengan siapa saja, bahkan dengan orang yang belum kita kenal sekalipun dari berbagai penjuru dunia, sebagai tempat promosi bagi seseorang ataupun kelompok yang bergelut di bidang usaha untuk mempromosikan produk/jasa yang kita tawarkan, mengembangkan keterampilan dan sosial, mengasah keterampilan teknis dan sosial merupakan kebutuhan yang wajib dipenuhi agar bisa bertahan hidup dan berada dalam neraca persaingan di era moderen seperti sekarang ini tidak ada batasan usia, semua orang butuh untuk berkembang.

Di luar dari berbagai hal positif yang ada pada media sosial, terdapat beberapa hal negatif yang di dapat oleh pengguna media sosial seperti kejahatan dunia maya dikenal dengan nama (cyber crime) seperti, carding, hacking, cracking, phising, dan spamming. Kemampuan penyampaian informasi yang dimiliki dapat dengan mudah mempengaruhi pengguna mulai dari unsur sara, perjudian, peredaran narkoba, hingga prostitusi.

Berikut salah satu contoh kejadian yang terjadi terdapat pada media sosial Instagram. Seperti diberitakan detik.com, pada bulan Oktober 2017. Sajikan Gadis Belia, Prostitusi Online di Lhokseumawe Dikelola 2 Wanita.

"Kakak beradik di kecamatan muara dua, kota Lhokseumawe, ditangkap anggota Satreskrim Polres Lhokseumawe. Keduanya diduga merupakan mucikari yang telah menjual para wanita muda kepada pria hidung belang". (https://news.detik.com/berita17/10/2017) diakses 19 Oktober 2017. 
Dari pemberitaan di atas menjelaskan bahwa media sosial dapat mengkhawatirkan berbagai pihak, juga dapat berdampak buruk bagi pengguna yang salah mempergunakan, mengkonsumsi konten media, tanpa memiliki pengetahuan literasi. Literasi media sendiri adalah pemahaman sumber teknologi dan komunikasi, yaitu, kode yang digunakan, pesan yang diproduksi pemilihan konten, penafsiran, serta dampak dari pesan tersebut.(Tamburaka, 2013:8).

Dalam paparan yang telah disebutkan di atas, maka dikhawatirkan pengguna aktif media sosial khusnya remaja, dimana usia mencari jati diri, rasa ingin tahu yang tinggi, serta membutuhkan berbagai edukasi yang dijadikan sebagai referensi. Namun sangat di sayangkan contoh berita di atas, telah mejelaskan jika seorang remaja telah menyalah gunakan media sosial, pengguna media sosial, tidak hanya mengakses dan mengkonsumsi konten media dengan berbagai aktifitas sosial, pesatnya pengguna dengan berbagai akun Black Mail yang menampilkan konten/postingan pornografi, provokasi, serta banyak hal lain yang di salah gunakan menjadi konsumsi remaja yang tidak sesuai dengan usianya.

Peneliti telah melakukan observasi awal dengan melihat beberapa akun media sosial khususnya (Instagram), dimana Instagram ini di rancang oleh Kevin Systrom dan Mike Krieger (Burbn, Inc) diresmikan pada Oktober 2010, Instagram sangat banyak digemari oleh kalangan muda karena kemudahan dan kecepatannya dalam berinteraksi secara global baik dalam bentuk tulisan, foto, dan video. Ditambah beberapa filter bergaya retro yang menarik, Instagram memberikan cara baru berkomunikasi secara visual. Dengan Konsep like, comment, follow, following, hastag, share, jika postingan masuk popular maka semakin menarik perhatian para penggunanya. (Bambang, 2012: 2).

Berdasarkan latar belakang masalah di atas, membuat peneliti tertarik untuk meneliti dan membuat sebuah karya ilmiah dengan judul "Literasi Bermedia Sosial Pada Remaja (Studi Pada Pengguna Instagram di Kota Lhokseumawe)", seperti yang telah diuraikan pada latar belakang di atas terdapat banyak hal negatif yang timbul pada media sosial saat ini, sehingga di khawatirkan pengguna media sosial instagram khususnya remaja yang tidak memiliki pengetahuan literasi dapat berdampak buruk dalam menggunakan akun media sosialnya. Hal tersebut tentu mengkhawatirkan, mengingat generasi muda telah menjadikan internet sebagai sebagai sumber rujukan utama dalam mencari informasi.

\section{Fokus Penelitian}

Adapun yang menjadi fokus masalah dalam penelitian ini adalah sebagai berikut : 
1. Proses literasi pada penggunaan akun Instagram.

2. Remaja Lhokseumawe, usia 12-18 Tahun yang menggunakan Instagram.

\section{Rumusan Masalah}

Berdasarkan latar belakang yang telah diuraikan, maka rumusan masalah yang akan diteliti adalah bagaimana literasi bermedia pada media sosial Instagram yang digunanakan remaja di kota Lhokseumawe

\section{Landasan Teori}

\section{Framework New Media Literasi}

Penelitian ini menggunakan Framework New Media Literacy. Framework new media literacy seperti yang ditunjukkan oleh dua continua yaitu: functional-critical dan consuming-prosuming yang terdiri dari empat macam literasi media baru: Functional Consuming, Critical Consuming, Functional Prosuming, Critical Prosuming, dimana empat macam literasi media tersebut akan di bongkar menjadi sembilan indikator Theoritical Framework sebagai sebuah model konseptual tentang bagaimana seorang peneliti berteori mengenai keterkaitan antara faktorfaktor yang telah teridentifikasi sebagai hal-hal yang penting bagi masalah. (Brown, 1998: 44).

Theoritical framework menggambarkan keterkaitan antar lebih dari satu variabel yang dianggap terintegrasi pada dinamika situasi yang sedang diteliti/diinvestigasi. Setelah masalah berhasil diidentifikasi, langkah selanjutnya adalah melakukan tinjauan pustaka untuk mencari variabel-variabel yang terkait/memiliki kontribusi terhadap masalah tersebut. Setelah variabel-variabel tersebut diidentifikasi, selanjutnya mengelaborasi keterkaitan/hubungan antara variabel tersebut, lalu diturunkan menjadi hipotesis yang relevan. Hipotesis tersebut kemudian akan dibuktikan dengan menggunakan metode analisis data yang sesuai. Theoretical framework selanjutnya akan menjadi landasan bagi seluruh proses penelitian. (Sekaran, 2009: 67).

Berikut adalah penjelasan Literasi Media dalam perspektif New Media Literacy yang terdapat dalam framework new media literacy:

1. Fungtional Consuming. Merupakan kemampuan individu untuk mengakses konten media dan memahami arti tekstualnya.

Fungtional Consuming dibagi menjadi dua indikator yaitu :

a. Consuming skill.

Mengacu pada serangkaian kemampuan teknis yang diperlukan individu ketika mengonsumsi konten media. Contohnya, seorang remaja perlu mengetahui bagaimana caranya mengoperasikan gadget 
seperti smartphone, laptop dan lainnya, bagaimana menggunakan teknologi informasi internet khususnya media sosial. (Brown, 1998: 57).

b. Understanding.

Merupakan kemampuan individu untuk menagkap arti dari konten media secara tepat di tingkat literal, termasuk kemampuan remaja untuk menangkap ide orang lain yang diterbitkan melalui media sosial dalam bentuk yang berbeda seperti teks, gambar, video, dan lain-lain serta kemampuan untuk menafsirkan arti sebuah format singkat terbaru seperti emoticon. (Brown, 1998: 58).

2. Critical Consuming. Merupakan kemampuan untuk menafsirkan konten media dalam konteks sosial, ekonomi, politik, dan budaya terentu.

Critical Consuming terdiiri dari tiga indikator yaitu :

a. Analysis.

Merupakan kemampuan individu untuk mendekonstruksi pesan media yang terkandung dalam konten media. Tidak seperti understanding yang dijelaskan di atas, indikator ini bisa dilihat sebagai 'analisis tekstual' semiotik fokus pada bahasa, genre, dan kode.

b. Synthesis.

Mengacu pada kemampuan individu untuk mencampur kembali konten media dengan mengintegrasikan sudut pandang mereka sendiri dan untuk mengkonstruksi pesan media. Misalnya, remaja dapat membandingkan informasi/konten media yang ada di media sosial dengan tema yang sama dari sumber yang berbeda.

c. Evaluation.

Mengacu pada kemampuan individu untuk mempertanyakan, mengkritisi, dan meragukan kredibilitas suatu isi/konten media. Dibandingkan analisis dan sintesis di atas, indikator ini merepresentasikan kritikalitas yang jauh lebih tinggi. Pada evaluasi ini menuntut remaja untuk menafsirkan konten media sosial dengan mempertimbangkan isu-isu seperti identitias (siapa pengarangnya), kepastian/kejelasan sumber, update atau tidaknya informasi. Evaluasi juga melibatkan proses pengambilan keputusan.

3. Functional Prosuming. Memfokuskan pada kemampuan untuk berpartisipasi dalam menciptakan konten media.

Functional Prosuming terdiri dari tiga indikator yaitu :

a. Prosuming Skill. 
Mengacu pada kemampuan teknis yang diperlukan individu untuk memproduksi atau menciptakan konten media. Seperti kemampuan remaja untuk menggunakan perangkat lunak (software) atau aplikasi yang tersedia dalam gadget untuk menghasilkan produk digital (konten baru) seperti gambar, video, dan lain-lain.

b. Distribution.

Mengacu pada kemampuan individu untuk menyebarkan informasi yang mereka dimiliki. Contoh relevannya termasuk kemampuan remaja menggunakan fungsi build-in pada media sosial untuk berbagi perasaan mereka (misalnya suka atau tidak suka), untuk berbagi pesan atau konten media, dan menilai suatu produk atau layanan, serta memfungsikan layanan bagikan atau share yang ada di facebook, line, Instagram dan lainnya.

c. Production.

Kemampuan untuk menduplikasi (sebagian atau seluruhnya) atau mencampur konten media. Tindakan production termasuk penulisan teks dalam format digital, membuat video dengan menggabungkan gambar dan audio, dan tulisan-tulisan online di media sosial seperti facebook, mengupload video dalam youtube dan media sosial lainnya.

4. Critical Prosuming.

Yaitu Participation, mengacu pada kemampuan untuk berpartisipasi secara interaktif dan kritis dalam media sosial. Secara interaktif menekankan interaksi bilateral antara individual. Contohnya remaja diharapkan secara aktif bekerja membangun dan memperbaiki ide orang lain (berkomentar) dalam media platform tertentu seperti facebook, twitter, Instagram, chat room dan lain-lain.

\section{Literasi Media}

Literasi Media adalah suatu rangkaian gerakan media, yaitu gerakan melek media dirancang untuk meningkatkan control individu terhadap media yang mereka gunakan untuk mengirim pesan dan menerima pesan. (Fantin, 2010:10) Sedangkan menurut David European, mendefinisikan literasi media adalah kemampuan untuk mengakses, menganalisis, dan mengevaluasi makna gambar, suara, pesan yang kita hadapi dalam kehidupan sehari-hari dan merupakan bagian penting dari budaya kontemporer, serta untuk berkomunikasi secara baik pada media yang ada secara pribadi. (David, 2011:45).

Namun, konsep literasi berkembang seiring dengan adanya perkembangan media, yang awalnya media tradisional (telepon, film, radio, televisi) perlahan merambah ke media baru seperti internet, media sosial, smartphone. Dengan munculnya media baru seperti media sosial 
yang merupakan salah satu bentuk inovasi dari internet pada awal abad 21 ini, literasi tradisional tidak lagi cukup untuk membuat seorang individu bertahan pada era media baru saat ini.

Media tidak hanya membentuk budaya kita, namun itu adalah budaya kita. Dengan kata lain, media baru memainkan sebuah peran penting dalam kehidupan masyarakat, dan individu perlu membekali diri mereka dengan literasi media baru. Literasi media baru dikaitkan dengan kemampuan menggunakan komputer, media sosial, dan internet. Penekannya bukan hanya tentang bagaimana orang menanggapi pesan media, tetapi juga pada bagaimana mereka terlibat secara proaktif dalam dunia media dimana produksi, partisipasi, kelompok sosial, dan level tinggi keahlian non professional yang umum. (Marketeers, 2013:102).

Pemahaman literasi media secara tradisional diartikan sebagai suatu kemampuan untuk mengakses, menganalisis, dan menciptakan. Literasi media adalah kemampuan untuk menganalisis dan menghargai karya-karya sastra, dan untuk berkomunikasi efektif melalui tulisan yang baik. Pemahaman literasi media pada tahun tujuh puluhan diperluas mencakup kemampuan untuk membaca teks film, televisi, dan media visual karena studi tentang pendidikan media dimulai dengan mengikuti pengembangan area media. (Ferrington, 2006: 87).

Sementara menurut Hobbs, literasi media adalah proses mengakses, menganalisis secara kritis pesan media dan menciptakan pesan dengan menggunakan alat media. (Hobbs, 1996: 97). Rubin menjelaskan bahwa yang dimaksud dengan literasi media adalah pemahaman sumber, teknologi komunikasi, kode yang digunakan, pesan yang dihasilkan, seleksi, interpretasi dan dampak dari pesan tersebut. (Rubin, 1998: 12). Dua komponen yang paling umum dari definisi literasi media yaitu adanya kesadaran dari banyak pesan media dan kemampuan kritis dalam menganalisis dan mempertanyakan yang dilihat, dibaca, dan ditonton (Singer, 1998: 100).

Lima konsep tentang literasi media menurut Center of Media Literacy sebagai berikut, semua pesan media "dikonstruksikan"; pesan media dikonstruksikan dengan bahasa yang kreatif sesuai dengan aturan mereka; individu memaknai pesan tergantung dari pemahamannya atas pesan yang ditangkapnya dari media; media mempunyai sudut pandang dan mengandung nilai tersendiri; hampir semua pesan media memiliki kepentingan keuntungan ataupun kekuasaan. (Sahre, 2005: 29).

Berdasarkan beberapa pendapat dari para ahli tentang literasi media saat ini, dapat dikatakan bahwa literasi media baru merupakan suatu kemampuan yang tidak hanya menekankan upaya melek terhadap berbagai macam pesan media yang di dalamnya melibatkan kemampuan 
mengakses, memahami, menganalisis, dan mengevaluasi isi pesan media secara kritis, melaikan juga melibatkan kemampuan individu dalam hal melakukan kegiatan pada dunia bermedia seperti produksi, partisipasi dalam bersosial.

\section{Elemen- Elemen Literasi Media}

Ada lima elemen dasar dari Literasi Media.(Rahmi, 2013:261) Adapun elemen-elemen dari Literasi Media tersebut adalah :

1. Sebuah kesadaran akan akibat dari media.

Menulis dan mencetak telah membantu mengubah dunia dan orangorang yang berada di dalamnya. Media massa juga melakukan hal yang sama. Bila individu menolak akibat media dalam kehidupannya, menghindari resiko yang akan didapat dan dibawa selama perubahan tersebut akan lebih baik dari pada membiarkan akibat tersebut merajalela.

2. Sebuah pemahaman mengenai proses dari komunikasi massa.

Apabila setiap individu mengetahui komponen-komponen dari proses komunikasi massa dan bagaimana komponen tersebut berhubungan satu sama lain, maka individu tersebut dapat membentuk harapan tentang bagaimana komponen tersebut dapat melayaninya. Bagaimana industri media yang bervariasi beroperasi. Apa kewajiban mereka terhadap penonton. Apa kewajiban penonton. Bagaimana media yang berbeda membatasi atau menambah pesan. Bentuk feedback yang bagaimana yang paling efektif, dan mengapa.

3. Strategi untuk menganalisa dan mendiskusikan pesan media.

Untuk mengkonsumsi pesan media dengan baik, setiap individu membutuhkan sebuah pondasi sebagai dasar berpikir dan refleksi. Apabila seorang individu membuat suatu pengertian, maka haruslah memiliki alat yang dapat melakukan itu (sebagai contoh, memahami maksud dan akibat yang ditimbulkan dari film dan video seperti angle kamera dan pencahayaan, atau strategi di balik penempatan foto pada halaman koran).

4. Sebuah pemahaman mengenai isi media sebagai sebuah Teks.

Bagaimana mengetahui sebuah kebudayaan dan individu yang berada didalamnya, sikap, nilai, perhatian, dan mitos-mitos. Hal tersebut dapat diketahui melalui komunikasi. Untuk kebudayaan modern, pesan yang disampaikan media meningkat tajam dan mendominasi dalam kehidupan.

5. Kemampuan untuk menikmati, memahami, dan menghargai isi media. Dimana harus memiliki kemampuan untuk memahami, menikmati serta menghargai segala isi yang terdapat pada media hingga tidak 
terdapat kesalahan dalam memaknai isi yang diperoleh dari sebuah media.

\section{Metode Penelitian}

Adapun metode dalam penelitian ini adalah metode kualitatif yang bersifat deskriptif. Moleong $(2006,190)$ penelitian kualitatif merupakan suatu pendekatan dalam melakukan penelitian yang berorientasikan pada gejala atau fenomena yang bersifat alami. Mengingat orientasinya demikian maka sifatnya mendasar dan naturalistik atau bersifat kealamiahan serta tidak bisa dilakukan di laboratorium melainkan dilapangan. Data yang diperoleh bersifat deskriptif yang berupa kata-kata lisan atau ungkapan dan gambaran di mana data tersebut diperoleh dari hasil wawancara dan pengamatan. Pendekatan ini menyebutkan bahwa tindakan manusia menjadi suatu hubungan sosial bila manusia memberikan arti atau makna tertentu terhadap tindakannya. Sehingga data yang berada di lapangan mampu mengungkapkan interpretasi subyek akan perilakunya. (Moleong,2006:6).

\section{Hasil Penelitian dan Pembahasan}

\section{Sosial Media yang Aktif Kalangan Remaja}

Memasuki era digital, internet menyajikan bermacam media sosial yang dapat digunakan oleh pengguna, antara lain anak-anak dan remaja kota Lhokseumawe mencoba berbagai media sosial dan pesan instan, media sosial yang mereka coba misalnya: Facebook, Whatsapp, Instagram, Snapchat, LINE, Google+, Youtube, BBM, Joox, Wattpad, Musical.ly, Vine, dan yang lain.

Bermedia sosial juga memiliki perarturan tertentu bagi penggunanya, tidak sebebas-bebasnya, semua media sosial seperti Facebook, Whatsapp, Instagram, Snapchat, LINE, Google+, Youtube, BBM, Joox, Wattpad, Musical.ly, Vine memiliki peraturan tertentu.

Peraturan media sosial terkadang dari pemerintah negara, dan yang paling dominan adalah dari perusahaan yang bersangkutan, seperti Facebook dibuat oleh perusahaan Facebook.

Menurut Saifullah Hasan (L/28), seorang pengamat media sosial kota Lhokseumawe mengatakan:

"Tidak semua sosial media digemari oleh anak-anak adan remaja kota Lhokseumawe, anak dan remaja paling terlibat dengan empat sosial media, yaitu: Facebook, Instagram, Whatsapp, BBM. Artinya, empat media sosial tersebut memiliki intensitas paling tinggi di antara media sosial yang lain".(wawancara, Hasan pada 04 Mei 2018) 
Berdasarkan hasil wawancara di atas dapat peneliti simpulkan hanya empat sosial media yang digemari pengguna. Dari hasil analisa peneliti ada beberapa penyebab mengapa anak dan remaja paling menggemari empat media sosial tersebut, yaitu :

“...Anak-anak seusia mereka juga menggunakan ke empat media sosial, terutama teman-teman sekitar. Keempat sosial media tersebut memiliki fitur yang memungkinkan anak dan remaja untuk mengawasi (watching), berkomunikasi, membagikan informasi, mengkonsumsi konten berupa (tulisan, foto, video), juga saling terhubung dalam bentuk (fiture inbox chat)".

“....Keempat media sosial tersebut memberi wadah untuk berpartisipasi baik secara personal atau individu dalam komunitas yang sesuai dengan minat mereka”.

“....Keempat sosial media tersebut memiliki platform applikasi mobile. Sehingga pengguna tetap terhubung satu sama lain tanpa batas ruang dan waktu Keempat sosial media tersebut memiliki fungsi hiburan".

Hal tersebut sesuai dengan aktifitas anak dan remaja terkait dengan media sosial, yaitu :

"....Menyatakan eksistensi diri dengan mengomentari foto dari teman-teman mereka di akun media sosial. Mendekatkan diri dengan follower dan friends melalui aktivitas memberi komentar atau chatting. Mencari informasi terkini karena keingintahuan mereka. Mencari teman yang memiliki minat yang sama".

“....Menyalurkan minat mereka dengan mencari informasi dan terlibat dalam aktivitas online. Mengunggah hasil aktualisasi mereka, termasuk foto, lagu dan video. Menggunakan media sosial sebagai sarana hiburan, termasuk bermain game".

Namun, pada penelitian ini, peneliti hanya menjadikan instagram sebagai media objek penelitian. Instagram adalah media sosial berada pada urutan kedua yang banyak digunakan oleh masyarakat dari berbagai kalangan. Instagram banyak diminati oleh para penggemar foto dan vidio, 
bahkan banyak yang menjadikan instagram sebagai album khusus koleksi foto pribadi yang hanya dibagikan kepada teman.

Walaupun beberapa platform media sosial memiliki layanan yang sama, namun setiap media sosial memiliki karakteristiknya sendiri-sendiri. Karakterstik setiap platform media sosial ini yang menjadikan daya tariknya pada setiap tahapan usia, gender dan latar belakang sosial menjadi berbeda.

Tidak hanya publik figure atau instansi pemerintah, pengguna instagram juga dari kalangan remaja, bahkan anak-anak yang memiliki hobi berfoto, membuat video yang dapat di koleksi dalam sebuah aplikasi ini.serta dapat di bagikan secara komersil. Semakin banyak follower maka semakin membuat tertarik pemilik akun dengan media sosial ini. Foto yang diupload ke instagram di buat semenarik mungkin dengan berbagai fiture yang telah tersedia pada platform media ini. Dengan begitu postingan pemilik akun yang di unggah mendapat banyak like atau komentar dari followers.

\section{Literasi Bermedia Sosial Instagram Pada Remaja Kota Lhokseumawe}

Pemahaman literasi media secara tradisional diartikan sebagai suatu kemampuan untuk mengakses, menganalisis, dan menciptakan. literasi media adalah kemampuan untuk menganalisis dan menghargai karya-karya sastra, dan untuk berkomunikasi efektif melalui tulisan yang baik. Pemahaman literasi media pada tahun tujuh puluhan diperluas mencakup kemampuan untuk membaca teks film, televisi, dan media visual karena studi tentang pendidikan media dimulai dengan mengikuti pengembangan area media.

Seiring perkembangan teknologi informasi dimulai dengan adanya perangkat komputer. Kemunculan Internet pada akhir 1960 berawal dari usaha yang dilakukan oleh Departemen Pertahanan Amerika Serikat untuk membuat jaringan komunikasi yang dapat digunakan dalam konflik nuklir. Penelitian awal dan pengembangan yang dilakukan di bawah naungan Advanced Research Projects Agency (ARPA) yang melibatkan individu yang dipilih beberapa di universitas riset Amerika Serikat. Oleh karena itu, jaringan yang dihasilkan di akhir tahun 1960 dikenal sebagai ARPANET.

Instagram termasuk media baru yang banyak digemari oleh remaja dan anak-anak, mereka banyak mengaksesnya dengan menggunakan handphone sesuai dengan yang disampaikan oleh Muhammad Nur Ichsan (L/18th) :

"awal mula saya menggunakan Instagram saat pertama sekali memiliki android, ketika semua teman saya telah 
menggunakan instagram maka saya tertarik pula untuk menggunakannya".

"saya masuk (login) pada aplikasi instagram dengan mendaftarkan alamat email serta mengisi nomor hp untuk mendapatkan kode verifikasi, setelah kode verifikasi di konfirmasi melalui pesan singkat tinggal masukkan kode yang di berikan agar terdaftar akun pada aplikasi instagram". (wawancara, Muhammad Nur Ichsan pada 04 Mei 2018)

Berdasarkan hasil wawancara di atas, maka analisa peneliti bahwa remaja memiliki kemampuan untuk mengoperasikan, mengakses, Aplikasi yang ingin di gunakannya, tanpa kesulitan mereka dapat melakukan tahap awal penggunaan media sosial. Menguasai kompleksnya pengetahuan tentang media baru serta rasa keingintahuan yang tinggi menjadikan mereka harus memiliki media sosial meski pemahaman yang di dapat secara otodidak, baik itu pemahaman tersendiri ataupun pada sebuah individu.

Sedangkan menurut Muhammad Iqbal (L/18th) :

"pertama saya mengenal aplikasi instagram sejak masuk SMK, saya merasa harus memiliki kemampuan memahami dan mengenal kemajuan teknologi maka menuntut saya untuk menggunakannya. Pertama saya melakukan pendaftaran dengan menggunakan email kemudian login akun dengan email yang telah terdaftar". (wawancara, Muhammad Iqbal 05 Mei 2018)

Berdasarkan wawancara di atas, menurut analisa peneliti langkah paling dasar adalah mengenal dan memahami media yang kita tekuni atau gemari, maka pengajaran tentang melek media (literasi media) dalam Consuming Skill yang mengacu pada serangkain teknis, serta Understanding yang merupakan kemampuan menangkap arti konten untuk saat ini seharusnya dimasukkan kedalam kurikulum.

Menurut Almira Raisya (P/14th) :

"saya menggunakan instagram karena aplikasinya telah ada pada android, mengingat banyak teman yang menggunakannya, maka tidak ada salah saya coba menggunakannya. Pendaftaran gratis, mudah, mendaftarkan email ke instagram untuk membuat akun aplikasinya" (Wawancara, Almira 05 Mei 2018) 
Hal yang sama juga disampaikan oleh Anggun Salsabila (P/17th) :

"saya tertarik dengan instagram ketika telah banyak menggunakannya, awalnya aktif facebook, namun setelah banyak yang menggunakan instagram, maka ikut menggunakannya. pertama mendaftar di instagram dengan menggunakan email, setelah akun terdaftar maka bisa masuk kapan saja”. (Wawancara, Anggun 06 Mei 2018)

Tidak jauh berbeda, Yusrina (P/18th) juga mengatakan :

"saya menggunakan Instagram karena tertarik apalagi telah banyak menggunakannya, membukanya dengan menggunakan handphone android. Pertama mendownload aplikasi kemudian mendaftarkan dengan menggunakan email yang masih aktif". (Wawancara, Yusrina 06 Mei 2018)

Pada penyampaian di atas, maka peneliti menyimpulkan apa yang telah disampaikan oleh informan yaitu Instagram adalah sebuah aplikasi layanan media sosial dengan biaya pendaftaran gratis, instagram dijalankan dengan cara men Sign-up ke akun instagram yang dimiliki, kriteria sign-up adalah dengan cara mengunduh aplikasi, membuat nama akun, memasukkan email dan password, usia minimal boleh menggunakan instagram adalah 10 tahun, layanan ini bersifat publik dengan memberikan pelayanan Friending, Following, Foto dan video, layanan ini menggunakan Platform Broser dan Aplikasi Instagram". Dengan demikian menunjukkan bahwa informan telah menguasai Fungtional Consuming. Dimana kemampuan individu untuk mengakses konten media dan memahami konten tekstualnya

Kemudian perlunya pengajaran khusus terhadap literasi media, agar para remaja pengguna media sosial memiliki etika terhadap konten media sosial serta etika bermedia yang sedang berkembang. Kegiatan ini tetap dalam pengontrolan orang tua dan guru, karena instagram adalah sosial media yang diperbolehkan kepada pengguna umur 10 tahun ke atas, maka dibawah kedewasaannya harus dalam pengawasan.

Etika konten media, yaitu tentang bahasa, genre, serta kode yang digunakan, dapat membandingkan informasi/konten media yang dibagikan, rata-rata untuk publikasi baik itu berupa tulisan, foto dan video. Hal demikian dikatakan oleh Muhammad Nur Ichsan (L/18th), bahwa :

"saya sering sekali menggunakan instagram untuk membagikan foto, video dan juga melihat foto dan video di 
feed (kabar) yang di postingkan orang lain. Kalau ada yang tidak layak seperti ada komentar tidak beretika atau menggunakan bahasa kotor, tidak saya respon.”. (wawancara, Muhammad Nur Ichsan pada 06 Mei 2018)

Dari hasil wawancara dapat peneliti simpulkan bahwa keburukan sangat banyak ditimbulkan oleh media terutama di media sosial, maka penting adanya pembahasan dan pengenalan terhadap media sosial terutama media baru yang sedang berkembang.

Instagram merupakan salah satu media sosial yang di dalamnya terdapat hal positif dan negatif, apalagi penggunaannya bersifat publik maka sangat rentan dengan hal-hal yang negatif, seperti pertikaian yang di picu oleh timbulnya propokasi, penyediaan akun-akun pornografi. Disinilah perlunya etika pengguna dan etika media sosial ketika bersinggungan dengan media dalam melakukan literasi.

Menurut Muhammad Iqbal (L/18th) hal yang sering dilakukan ketika mengakses Instagram adalah :

"saya hanya melihat foto yang dibagikan orang lain, kadang juga membagikan foto, video dan juga membuat stories, Jika ada foto yang tidak layak maka tidak perlu dilayani atau dilewati saja tanpa meresponnya". (wawancara, Muhammad Iqbal pada 07 Mei 2018)

Berbicara tentang instagram, merupakan salah satu media sosial yang digemari oleh remaja bahkan anak-anak dalam berkomunikasi dan mempublikasikan kehidupannya sehari-hari. Sebagaimana juga yang disampaikan oleh Almira Raisya (P/14th) :

"saya suka sering melihat video Korea, foto teman, dan membuat stories. Kalau ada foto tidak layak maka saya lewatkan". (wawancara, Almira pada 04 Mei 2018)

Hasil dari wawancara peneliti menyimpulkan bahwa media sosial seperti instagram sudah menjadi kebutuhan, agar tetap saling terhubung satu sama lain, melakukan komunikasi, memcari informasi dan berbagi informasi.

Bentuk-bentuk komunikasi seperti direct (pesan) langsung antar pengguna, berbagi informasi dalam Feed (kabar), memberi komentar dan sebagainya dapat dilakukan pada platform media sosial Instagram. Di media sosial tersebut juga dapat menjalin pertemanan dengan orang yang relatif atau sama sekali belum dikenal di dunia nyata dengan menambah (follow) mengikuti akun Instagram orang lain. Merupakan hal yang 
menarik bagi pengguna akun ketika dapat mengikuti akun Instagram artis atau publik figur yang di idolakannya, mengamati dan memperbincangkan segala sesuatu yang dilakukan oleh idola baik dalam stories maupun feed .

Lebih lanjut Anggun Salsabila (P/17th) menambahkan bahwa :

"saya tertarik terhadap media sosial instagram karena dapat membantu saya dalam melihat akun olshop, melihat barang online yang di tampilkan bagus untuk memudahkan saya berbelanja". (wawancara, Anggun pada 04 Mei 2018)

Analisa peneliti bahwa media sosial bisa memberi keuntungan kepada penggunanya jika dimanfaatkan dengan benar. Seperti yang disampaikan oleh Anggun Salsabila menggunakan instagram sebagai media sarana untuk berbelanja sebuah kebutuhan, hal ini dapat membantu perekonomian jika digunakan secara cerdas oleh pengguna khususnya remaja.

Selain hiburan yang dapat di sajikan, instagram juga dapat di jadikan sebuah ranah edukasi, menyajikan tutorial dalam bentuk video, yang dapat dijadikan sebuah referensi yang membuat pengguna melihat dan memilih konten sesuai dengan kesukaan dan keinginanya.

Seperti yang disampaikan oleh Yusrina (P/18th), bahwa :

"saya suka melakukan Instag Stories dengan instagram, melihat video tutorial hijab, mengikuti akun-akun hijaber dan religius ". (wawancara, Yusrina pada 05 Mei 2018)

Peneliti bisa menyimpulkan bahwa ketertarikan itu berawal dari terpenuhinya hasrat hati dan impian. Bisa membantu pekerjaan, memberikan kenyamanan, memenuhi keinginan.

Menurut peneliti, ruang tersebut menjadi arena bagi pengguna untuk berpartisipasi secara aktif maupun pasif terkait dengan berbincang dan saling berkomunikasi dalam bentuk tulisan maupun gambar yang mereka sukai. Seperti yang disampaikan Yusrina ini sangat membantu wanita-wanita berhijab untuk belajar memodifikasi hijabnya lebih modern dan tetap syar'i. Hal ini menunjukkan bahwa remaja melakukan Analysis dengan mendekonstruksi pesan media yang terkandung dalam konten media, membandingkan baik benarnya konten media secara Syntesis meragukan kredibilitas suatu konten media dalam Evaluation juga melibatkan proses pengambilan keputusan dalam konsumsi konten media.

Instagram merupakan sesuatu yang populer digunakan oleh remaja untuk memenuhi kebutuhan mengikuti perkembangan zaman, menciptakan konten serta dapat memduplikasikan agar dapat saling berpartisipasi sekaligus memberikan pengalaman berkompetisi, 
berinteraksi dengan beberapa orang di luar sana yang juga menggunakannya secara real time.

Alasan lain yang menyebabkan instagram menjadi sesuatu yang menarik bagi remaja adalah karena media sosial tersebut dapat dimanfaatkan sebagai sarana akumulasi penguatan identitas terkait dengan relasi mereka dengan teman-temannya. Apabila anak absen atau tidak menggunakan media sosial yang serupa dengan teman-teman, termasuk tidak melakukan apa yang teman mereka lakukan di media sosial maka mereka akan menghadapi kemungkinan ketinggalan berita atau kurang update. Hal ini membuat remaja harus cerdas dalam menciptakan konten media seperti kemampuan untuk menggunakan perangkat lunak (Software) untuk menghasilkan produk digital (konten baru).

Menyebarkan informasi secara Distribution yang mereka miliki juga termasuk kemampuan menggunakan fungsi build-in pada media sosial untuk berbagi perasaan mereka dalam suka atau tidak sukanya pada suatu konten media yang di dapat pada feed (kabar berita) begitu juga dalam Production dimana kemampuan remaja dalam menduplikasikan sebagian atau seluruhnya.

Seperti yang disampaikan oleh Muhammad Nur Ichsan (L/18th) :

"Instagram memudahkan saya dalam hobi Fotografer, mengupload foto, melihat hasil foto-foto para fotografer hebat untuk dijadikan contoh, bertanya hal-hal baru dalam komentar pada postingan para fotografer, ya sedikit menambah pengetahuan saya dalam hobi yang saya geluti saat ini". (wawancara, Muhammad Nur Ichsan pada 06 Mei 2018)

Dari hasil wawancara (Muhammad Nur ichsan) peneliti dapat menyimpulkan bahwa remaja menggunakan media sosial sebagai tempat dimana terjadinya interaksi yang dapat di jadikan sebuah refensi, berdasarkan minat atau ke ingintahuan yang tinggi.

Menurut Muhammad iqbal(L/18th) :

"Instagram memudahkan saya dalam sebuah informasi, melihat lihat berita, berkomentar pada postingan temanteman alumni sekolah dulu, ya melepas kangen meski tidak jumpa" (wawancara, Muhammad Iqbal pada 07 Mei 2018)

Hal serupa juga di sampaikan oleh Almira Raisya (P/14th) : 
"Mengomentari postingan teman, sukai, chatting Direct sama teman aja kalau lagi ngak jumpa" (Wawancara, Almira 05 Mei 2018)

Menurut Anggun Salsabila (P/17th) :

"Partisiapasi paling dengan teman yang saya kenal saja, berkomentar, menyukai postingan, berbelanja keperluan seperti jilbab, baju di akun-akun olshop" (Wawancara, Anggun 06 Mei 2018)

Menurut Yusrina (P/18th) juga mengatakan :

"Instagram memang digunakan untuk berpartisipasi satu sama lain, cuma terkadang banyak yang usil juga, seperti berprovokasi merusak hubungan komunikasi, Cuma itu semua menurut kitanya juga sih" (Wawancara, Yusrina 06 Mei 2018).

Berdasarkan hasil wawancara peneliti dengan beberapa informan di atas tentang "literasi bermedia sosial instagram pada remaja kota Lhokseumawe" memberikan kesimpulan bahwa instagram adalah media sosial baru setelah facebook, yang banyak digunakan oleh remaja dan anak-anak, menggunakan media sosial untuk pemenuhan hasrat mereka dalam berkomunikasi, berinteraksi, mencari hiburan, serta menjadikan sebuah referansi. Beberapa jenis hiburan yang dapat mereka temukan di instagram diantaranya berupa tulisan, foto, video, dan lain sebagainya secara visual.

Media sosial dimanfaatkan pula sebagai ruang untuk berbagi informasi-informasi pribadi, Seperti mempublikasikan aktifitas dalam kesehariannya, mengungkapkan perasaan, dengan didukung oleh beberapa fiture yang dapat digunakan oleh penggunanya.

Pengguna bisa menggunakan berbagai nama asli maupun dengan kode tertentu, menulis dengan gayanya sendiri, dan menunjukkan personalitinya yang tidak bisa ditunjukkan di dunia nyata. Media sosial memungkinkan lebih banyak bentuk ekspresi diri dan ruang untuk refleksi diri. Dengan demikian, berdasarkan hasil wawancara di atas menunjukkan bahwa para informan telah menguasai Fungtional consuming, Critical consuming, Fungtional prosuming dan Critical presuming, meski tidak didapat dari pelajaran sekolah atau kurikulum khusus ke empat perspektif new media literasi ini di jalankan secara naluri oleh remaja itu sendiri, kesadaran memilih sebuah hal yang baik dan benarnya suatu konten media dijadikan sebuah hal baik dalam kehidupan sehari-hari. 


\section{Pembahasan}

Peneliti menggunakan teori Framework New Media Literasi dalam melakukan penelitian ini, yaitu dengan melihat dan meneliti remaja yang melakukan interaksi mendalam dengan sosial media atau disebut dengan melek media di kota Lhokseumawe. Peneliti meneliti kemampuan remaja untuk mengakses, menganalisis, dan mengevaluasi makna gambar, suara, pesan yang dihadapi dalam kehidupan sehari-hari dan merupakan bagian penting dari budaya kontemporer, serta untuk berkomunikasi secara baik pada media yang ada secara pribadi. Namun, konsep literasi berkembang seiring dengan adanya perkembangan media, yang awalnya media tradisional (telepon, radio, televisi) perlahan merambah ke media baru seperti internet, media sosial, smartphone. Dengan munculnya media baru seperti media sosial yang merupakan salah satu bentuk inovasi dari internet pada awal abad 21 ini, literasi tradisional tidak lagi cukup untuk membuat seorang individu bertahan pada era media baru saat ini.Dalam penelitian ini peneliti melakukan dengan menggunakan empat konsep literasi, yaitu :

Pertama, Functional Consuming merupakan kemampuan individu untuk mengakses konten media dan memahami arti tekstualnya. Melakukan pengenalan terlebih dahulu dengan perangkat yang akan digunakan adalah jalan paling tepat agar tidak menjadi bumerang dikemudian hari. Ini harus dilakukan sedetil mungkin demi kenyamana pengguna instagram dari orang yang tidak bertanggung jawab, mulai dari cara mengoperasikan instagram yaitu dengan cara mengunduh aplikasi secara gratis, kemudian masuk ke aplikasi dengan menggunakan alamat email dan password, layanan ini berbentuk publik yang dapat lihat semua orang.

Pada konsep pertama (Functional Consuming) peneliti telah menemukan kemampuan remaja dalam menjalankan aplikasi instagram. Remaja kota Lhokseumawe mengerti dan memahami mulai dari mengunduh aplikasi, kemudian mendaftar akun dengan menggunakan email sampai mengakses ke akun yang telah terdaftar.

Kedua, Critical Consuming merupakan kemampuan untuk menafsirkan konten media dalam konteks sosial, ekonomi, politik, dan budaya terentu. Instagram adalah media sosial baru yang banyak digemari oleh anak-anak dan remaja dewasa ini. Layanan sosial ini menyajikan platform yang menarik yaitu dengan pemajangan foto dan video pengguna ke dunia maya yang bisa disaksikan oleh semua pengguna instagram.

Pada konsep kedua (Critical Consuming) peneliti menemukan dari hasil wawancara bahwa remaja kota Lhokseumawe telah mempu 
membedakan konten yang ada dalam media sosial khususnya instagram. Hal ini dapat peneliti lihat dari cara mereka menyikapi setiap konten yang tampil, jika berkenaan dengan pornografi maka dilewatkan, begitu juga dengan konten politik tidak mendapat respon yang baik dari remaja, mereka sangat memahami apa yang mereka suka dari konten yang menarik.

Ketiga, Functional Prosuming memfokuskan pada kemampuan untuk berpartisipasi dalam menciptakan konten media. Melalui isntagram sebagai media baru, pengguna bisa memperkenalkan identitasnya kepada lawan komunikasi di dunia maya walaupun pengguna media sosial tersebut menggunakan identitas ganda (palsu). Tanpa adanya media baru, identitas diri sudah merupakan sesuatu yang kompleks. Remaja menjadi masa yang paling rawan dalam tahapan perkembangan individu. Media baru menyediakan "bantuan" dalam pembentukan identitas remaja. Bantuan tersebut selayaknya digunakan dengan bijaksana untuk menghindari hal yang tidak perlu. Pemahaman akan pemanfaatan identitas ganda yang ditawarkan media baru menjadi sesuatu yang berguna bagi remaja. Tanpa pemahaman yang mendalam mengenai berbagai diri yang diekspresikan secara virtual, kita tidak bisa menggunakan pengalaman kita untuk memperkaya identitas yang nyata.

Konsep ketiga ini peneliti menemukan Fuctional Prosuming, peneliti menemukan kemampuan remaja kota Lhokseumawe dalam menciptakan konten media, mereka memahami bagaimana cara memperkenalkan identitasnya di media sosial tersebut, membuat status, menampilkan foto dan membuat video, semua dilakukan atas pengertian mereka terhadap kegunaan instagram tersebut.

Pengguna tidak perlu cemas dan takut dengan mempublikasikan identitas nyata, karena pada media sosial seperti instagram ada ruang privasi yang disediakan oleh aplikasi tersebut.

Privasi mengarah pada bagaimana data pribadi seseorang dan informasi mengenai orang lain ditangani dalam konteks sosial. Ketika identitas merupakan kumpulan berbagai informasi mengenai seseorang, maka privasi lah yang menentukan informasi mana yang seharusnya ditunjukkan dan mana yang disembunyikan. Privasi berkaitan dengan self disclosure, keterbukaan diri yang dimiliki seseorang, apa yang akan dikomunikasikan seseorang mengenai dirinya sendiri kepada orang lain. Self disclosure antara lain meliputi: nilai dan kepercayaan, perilaku, dan kualitas diri.

Bagi banyak remaja, privasi bukanlah mengenai menyembunyikan informasi personal tapi lebih pada bagaimana mengaturnya secara berhatihati - apa yang dibagi, bagaimana mempresentasikannya, dan siapa yang 
mengaksesnya. Dan hal ini diakomodasi oleh setting privasi, seperti di Facebook, dimana kita bisa menentukan, bukan hanya informasi apa saja yang kita ingin tunjukkan, melainkan juga siapa saja yang bisa mengakses informasi tersebut. Contoh, foto, note, atau status yang disetting untuk bisa dilihat orang-orang tertentu saja. Hal ini bukan saja bisa mengendalikan privasi seseorang, tapi juga mengatur seperti apa privasi mereka.

Keempat, Critical Prosuming merupakan kemampuan untuk berpartisipasi secara interaktif dan kritis dalam media sosial. Secara interaktif menekankan interaksi bilateral antara individual. Contohnya remaja diharapkan secara aktif bekerja membangun dan memperbaiki ide orang lain (berkomentar) dalam media platform tertentu seperti facebook, twitter, instagram, chat room dan lain-lain.

Salah satu tindakan yang menunjukkan hal tersebut yaitu berbagi status mengenai apa yang sedang mereka lakukan dan rasakan di berbagai platform media sosial yang mereka gunakan. Berbagi status terkait pula dengan fakta bahwa mereka juga terhubung dengan teman-teman mereka sehingga segala sesuatu yang dibagikan berpotensi diterima dan dicerna serta dikomentari.

Salah satu tindakan yang paling lekat dalam keseharian anak dan remaja di media sosial adalah chatting, berbagi photo dan video atau bercakap-cakap dengan orang lain sesama pengguna aplikasi (instant messenger). Pengguna lain ini dapat mencakup teman, keluarga hingga orang yang relatif belum dikenal sama sekali.

Menurut Tamburaka (2013) dalam literasi media sosial maka cukup melihat tiga kriteria yaitu kompunen, tipe dan manfaat. Langkah pertama adalah menliti aplikasi layanan sosial tersebut, kemudian melihat tipe layanan sosial apakah berbentuk privat atau publik, selanjutnya melihat manfaat yang ditimbulkan oleh media tersebut. Ketiga kriteria yang disebutkan oleh Apriadi Tamburaka telah penulis bahas dalam penelitian penulis dan termasuk dalam konsep literasi media yang penulis bahas.

Konsep yang ke empat yaitu Critical Prosuming, pada konsep ini, kemampuan menerima dan memberi, peneliti menemukan dua tipe remaja pada konsep ini, yaitu tipe yang bisa menerima dan memberi, kedua tipe yang hanya bisa menerima saja. Maksud peneliti pada tipe pertama adalah remaja yang mempu mencerna setiap pesan kemudian dia merespon pesan tersebut sesuai dengan tujuan dari pesan tersebut. Tipe yang kedua adalah remaja yang mempu mencerna pesan tersebut tetapi tidak memiliki kemampuan untuk meresponnya. Jadi, tidak semua remaja memiliki critical prosuming berdasarkan hasil penelitian yang peneliti lakukan. 


\section{Kesimpulan}

Hasil penelitian ini menunjukkan bahwa remaja telah menguasai Functional Consuming, dilihat dari kemampuannya dalam menggunakan dan menjalankan aplikasi Instagram dengan cara men Sign-up ke akun instagram yang dimiliki, kriteria sign-up adalah dengan cara mengunduh aplikasi, membuat nama akun, memasukkan email dan password. Informan telah menguasai Critical Consuming, dilihat dari kemampuannya dalam menafsirkan setiap konten media yang tampil, bisa membedakan baik dan buruk, sosial, ekonomi dan budaya. Remaja telah mengerti cara berbisinis di media sosial seperti instagram, mengerti cara berinteraksi dengan orang yang tidak dikenal secara langsung. Informan telah menguasai Fungtional Prosuming, dilihat dari kemampuannya dalam menciptakan konten seperti postingan berupa tulisan, foto atau video secara visual. Memperkenalkan dirinya ke media sosial baik dalam bentuk privasi atau public. Setiap remaja yang menggunakan instagram telah mempu menjalankannya dalam konsep Fungtional Prosuming. Dan informan juga telah menguasai Critical Prosuming. Dilihat dari kemampuan pemanfaatan Platform Instagram dalam mempublikasi konten dan memberi komentar terhadap konten yang dipublikasikan orang lain. Walaupun tidak semua remaja mempu memberikan komentar pada konten orang lain yang sesuai dengan maksud sipembuat konten. Pengguna media sosial terbagi menjadi dua, pertama mempu mencerna dan memberikan komentar yang sesuia, kedua mempu mencerna tetapi tidak mempu memberikan komentar yang sesuai dengan isi konten media. Pada konsep ini yang diharapkan remaja secara aktif bekerja membangun dan memperbaiki ide orang lain dalam berkomentar.

\section{Daftar Pustaka}

Bambang, A.D. (2012). Instagram Handbook, : Media Kita.

Baran, Stanley. J dan Dennis K. Davis. (2010). Teori Komunikasi Massa ( Dasar, Pergolakan, dan Masa Depan ). Jakarta: Salemba Humanika.

European, David (2011). Literasi Media. Jakarta: Grafindo.

Ferrington, (2006), What is media literacy, Jakarta: Agency.

Hasan, M. Iqbal, (2002).Pokok-pokok Materi Metodologi Penelitian dan Aplikasinya, Ghalia Indonesia, Bogor. 
Ihksan, (2012), Tesis Pengaruh Budaya Syi'ah Terhadap Perkembangan Kehidupan Masyarakat Kota Lhokseumawe. Banda Aceh: UIN Ar Raniry.

Marketeers, (2013), terjm New Media: A Critical Introduction. London: Routledge.

Moleong, Lexy J. (2005). Metode Penelitian Kualitatif, Bandung, PT. Remaja Rosda Karya.

Moleong, Lexy J. (2006) Metode Penelitian Kualitatif, Bandung, PT. Remaja Rosda Karya.

Movementi, S. (2014). Ponsel Pintar Pemula Paling Diminati. Bandung: Indo Group.

Notoatmodjo, S. (2007). Promosi Kesehatan dan Ilmu Perilaku. Jakarta : Rineka Cipta.

Pawito, (2007).PenelitianKomunikasiKualitatif . PT LKiSPelangiAksara.

Rahmi, A. (2013). Pengenalan literasi media pada anak usia sekolah dasar. SAWWA, Jakarta: Grafika Ilmu.

Rubin, A. (1998). Media Literacy: Editor's note. Journal of Communication, Semarang, Raja Grafindo.

Sahre, (2005), trjm Media Literacy, Media Activism. Telemedium, the Journal of Media Literacy. Bandung: Remaja Rosdakarya.

Santana, (2005), Psikologi Perkembangan Remaja: Suatu Pendekatan Sepanjang Rentang Kehidupan. Jakarta: Erlangga.

Sarlito Wirawan Sarwono. (2012).Psikologi Remaja. Jakarta: PT. Raja Grafindo Persada.

Sekaran, (2009), trjm Intoduction: Digital Media, Youth, and Credibility. Surabaya: MIT Press.

Setyani, (2013), Pendidikan Literasi Media Pada Pelajar. Bandung: Remaja Rosdakarya. 
Singer, D. G., \& Singer, J. L. (1998). Trjm Developing critical viewing skills and media literacy in children. Jakarta: Grafika Ilmu.

Soetjiningsih, (2004). Buku Ajar: Tumbuh Kembang Remaja dan Permasalahannya. Jakarta: Sagung Seto.

Tamburaka, Apriadi. (2013). Literasi Media: Cerdas Bermedia Khalayak Media Massa. (Jakarta: Raja Grafindo Persada.

Triyono, A. (2010). Pendidikan Literasi Media Pada Guru TK Gugus Kasunanan Sebagai Upaya Menanggulangi Dampak Negatif Televisi. Warta, Jakarta: Remaja Rosdakarya. 